\title{
The Effect of Catena Position on Greenhouse Gas Emissions from Dambo Located Termite (Odontotermes transvaalensis) Mounds from Central Zimbabwe
}

\author{
George Nyamadzawo ${ }^{1,2^{*}}$, Jephita Gotosa ${ }^{1}$, Justice Muvengwi ${ }^{1}$, Menas Wuta ${ }^{2}$, Justice Nyamangara ${ }^{3}$, \\ Philip Nyamugafata ${ }^{2}$, Jeff L. Smith ${ }^{4}$ \\ ${ }^{1}$ Department of Environmental Science, Bindura University of Science Education, Bindura, Zimbabwe \\ ${ }^{2}$ Department of Soil Science and Agricultural Engineering, University of Zimbabwe, Mount Pleasant, Harare, Zimbabwe \\ ${ }^{3}$ International Centre for Research in Semi Arid Tropics (ICRISAT) Matopos, Bulawayo, Zimbabwe \\ ${ }^{4}$ USDA-Agricultural Research Service, Washington DC, USA \\ Email: "gnyama@yahoo.com
}

Received June 11, 2012; revised July 13, 2012; accepted July 25, 2012

\begin{abstract}
Methane $\left(\mathrm{CH}_{4}\right)$, carbon dioxide $\left(\mathrm{CO}_{2}\right)$ and nitrous oxide $\left(\mathrm{N}_{2} \mathrm{O}\right)$ are greenhouse gases (GHGs) which cause global warming. Natural sources of GHGs include wetlands and termites. Previous studies have quantified GHG emissions from upland termites and no study has reported GHG emissions from seasonal wetlands (dambo) located termite mounds. The objective of this study was to evaluate the effect of dambo catena position on termite mound distribution and GHG emissions. It was hypothesized that mound density and GHG emissions from Odontotermes transvaalensis mounds, vary with catena position. The evaluated catena positions were margin, mid-slope, lower slope and bottom. Mound density was significantly lower in the bottom when compared to the other catena positions. The mean GHG fluxes were $88 \mu \mathrm{g} \cdot \mathrm{m}^{2} \cdot \mathrm{hr}^{-1}, 0.78 \mathrm{mg} \mathrm{m}{ }^{-2} \cdot \mathrm{hr}^{-1}$ and $1361 \mathrm{mg} \cdot \mathrm{m}^{-2} \cdot \mathrm{hr}^{-1}$ for $\mathrm{N}_{2} \mathrm{O}, \mathrm{CH}_{4}$ and $\mathrm{CO}_{2}$ respectively. Fluxes varied with catena position and were $0.48,0.72,1.35$ and $0.79 \mathrm{mg} \cdot \mathrm{m}^{-2} \cdot \mathrm{hr}^{-1}$ for $\mathrm{CH}_{4}$, and $1173.7,1440.7,1798.7$ and 922.8 $\mathrm{mg} \cdot \mathrm{m}^{-2} \cdot \mathrm{hr}^{-1}$ for $\mathrm{CO}_{2}$ in the margin, mid-slope, lower slope and the bottom catena position respectively. For $\mathrm{N}_{2} \mathrm{O}$, there were no significant differences between catena positions. It was concluded that dambo located Odontotermes transvaalensis termite mounds are an important source of GHGs, and emissions varied with catena position for $\mathrm{CO}_{2}$ and $\mathrm{CH}_{4}$.
\end{abstract}

Keywords: Greenhouse Gas Emissions; Termites Mounds; Odontotermes transvaalensis; Dambos; Catena Position

\section{Introduction}

Greenhouse gases (GHGs) are among the major causes of global warming [1]. The greenhouse effect occurs when greenhouse gases; methane $\left(\mathrm{CH}_{4}\right)$, carbon dioxide $\left(\mathrm{CO}_{2}\right)$ and nitrous oxide $\left(\mathrm{N}_{2} \mathrm{O}\right)$ trap long wavelength radiation that is reflected from the earth's surface, hence affecting the balance of heat radiation through the entire atmosphere, resulting in rising temperatures. Analysis has shown that atmospheric concentrations of methane have increased by approximately 145 percent since 1800 [2] and the $\mathrm{CH}_{4}$ atmospheric mixing ratios have increased by 2.5 times, reaching $1750 \mathrm{ppbv}$ (parts per billion by volume) in 2001 [3]. Among the three major GHGs, $\mathrm{N}_{2} \mathrm{O}$ has a bigger global warming potential (GWP). On a molecule for molecule basis, the GWP of $\mathrm{N}_{2} \mathrm{O}$ are 310 and 21 times more, than that of $\mathrm{CO}_{2}$ and $\mathrm{CH}_{4}$ respectively, over a 100 year time scale [1]. The residence time of $\mathrm{N}_{2} \mathrm{O}$

${ }^{*}$ Corresponding author. is 115 years compared to 100 years for $\mathrm{CO}_{2}$ whilst the ability to absorb infra red radiation is 216 greater than that of $\mathrm{CO}_{2}$ [4]. Thus, $\mathrm{N}_{2} \mathrm{O}$ is known for its long lasting greenhouse gas effect.

Sources of GHGs maybe anthropogenic e.g. rice paddies or natural e.g. wetlands $[3,5,6]$. Current estimates for $\mathrm{CH}_{4}$ emissions from wetlands are between 20 and $25 \%$ of the global annual emissions [6] and of this, $60 \%$ is from tropical wetlands. Central and Southern African regions are occupied by some of the largest seasonal wetlands in Africa. These seasonal wetlands which are commonly called dambos constitute the largest geographic extent of seasonal wetlands on the elevated plateaus of Africa $[7,8]$.

Dambos are seasonally saturated, grassy, gently sloping valley floors $[7,9,10]$, which are conservatively estimated at $20 \%$ of the gently undulating land surface of the Central African Plateau [7]. In Zimbabwe dambos cover an estimated 1.28 million hactares (ha) of land. Dambos are mainly used as pastures for livestock and for gardens 
in the smallholder farming sector. Dambos from Zimbabwe are normally divided into five basic soil-vegetation-topography units (catena positions) namely upland, margin; mid-slope; lower-slope and bottoms [11]. The general trend observed when moving from upland to bottom catena in areas underlain by mafic parent material, is an increase in soil organic matter (SOM) content [12-14] and an increase in clay contents. The clay content increases as a result of depositions of clay that is eroded from the margins and upland. The clay mineralogy in dambos may also change from non active clays in the margin, to active clays in the bottoms.

The gently sloping landscapes of dambos are interrupted by mounds which are formed by termites, Odontotermes transvaalensis [15] and are characterized by drier soils and frequently covered by trees $[14,16]$. Several Odontotermes species are common in the moist savannas of southern Africa, and species are specific to soil moisture regimes and to certain soil types [15]. Dambos of southern Africa are occupied by the Odontotermes transvaalensis species, and estimates are that they contain millions of termite mounds which are scattered throughout these gently undulating floors. Odontotermes transvaalensis species favour areas that are found throughout the central watershed of Zimbabwe with high water table, drainage lines and seasonally water logged areas (dambos) $[15,17]$. Dambos are mainly used as pastures, and the termite mounds provide good forage as they are always covered by grasses because of the high fertility of soils of the mounds [15]. Odontoterme transvaalensis build large termite mounds with a vent at the center. The mound maintains an equitable set of moisture and temperature conditions within the hive. Termite mound densities may be 10 mounds ha ${ }^{-1}$ ([18], while Schuurman and Dangerfield [17] reported densities of between 0.05 and 6 mounds per hectare (ha) in the seasonally flooded Okavango delta. In dambos not all mounds contain termites as some are abandoned. Termite mounds can also be categorized on the basis of activity, either as active or none active. Active mounds are those mounds which contain termites while inactive mounds are those that have been abandoned by termites. The proportions of live mounds are variable in dambos, for example, in southern Nigeria, [19] reported $60 \%$ live mounds for some species.

Although termite populations are active in the middle latitude environments, the highest concentration of mounds and nests are found in the tropical regions of Africa, Asia, Australia and South America which contribute approximately $80 \%$ of global termite mound emissions [20]. The role of termites in global carbon cycle in the savannas of Africa have been reported by several authors e.g. [20-26]. However, few studies have quantified termite mound densities in dambos e.g. [27] and [18]. The role of dambos termite on carbon and nitrogen cycling and
GHG emissions from central and southern Africa has been overlooked and is much less understood. From the available literature there is no reported data on GHG emissions from organic matter rich dambo located termite mounds from Zimbabwe, or the region which is covered by millions of hectares of dambos which contain millions of termite mounds. The few studies that have reported GHG emissions from termite mounds have focused mainly at GHG fluxes from upland e.g. [24,25,28]. This study is reporting the first dataset on GHG emissions from dambos located Odontotermes transvaalensis mounds from Zimbabwe. The objectives of the study were to quantify the effect of the catena position on termite mound density and on GHG emissions. It was hypothesized that termite mound densities vary with catena position and that GHG emissions from dambo located termite mounds also vary with catena position.

\section{Methodology}

\subsection{Study Sites}

The University of Zimbabwe Farm (UZF) is located 20 $\mathrm{km}$ North of Harare along the Mazowe road (GPS location $17^{\circ} 43^{\prime} \mathrm{S}, 31^{\circ} 00^{\prime} \mathrm{E}$ ), (Figure 1). The UZF is in Natural Region IIa with an annual rainfall varying from 700 $1000 \mathrm{~mm}$ which is received between November and April. The mean annual temperature ranges from 16 to $20^{\circ} \mathrm{C}$ [29]. The farm is located on a dolerite terrain and the site has heavy-textured soils (red clay; Chromic luvisol). The soil changes from a red colour in well drained areas to grey and black in the dambos. The seasonally waterlogged dambos at the UZF are mainly used as pastures for livestock and are surrounded in uplands by maize, soya bean fields and miombo woodlands. Gas

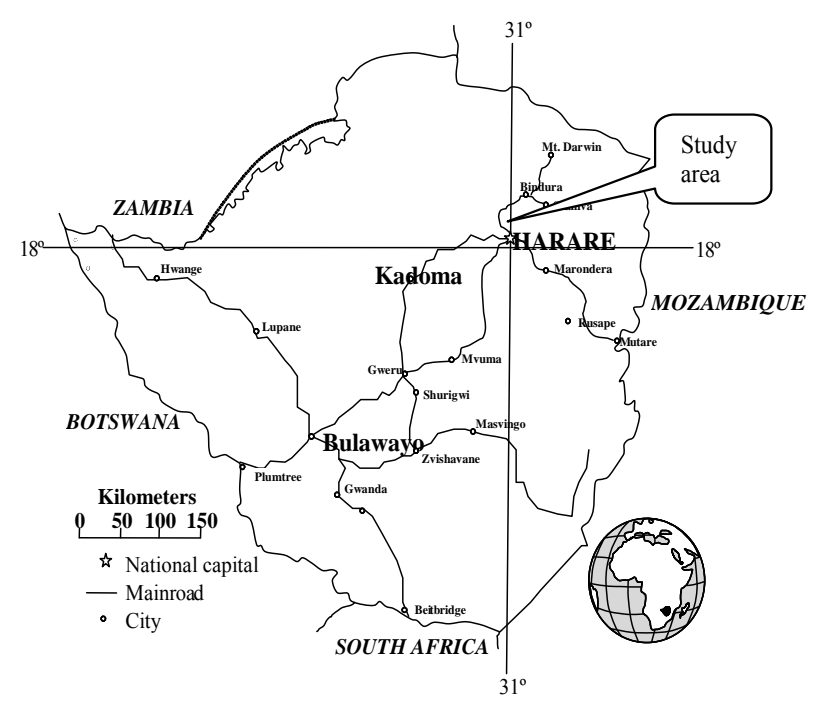

Figure 1. The Zimbabwe map showing the study site, University of Zimbabwe Farm (UZF). 
samples were collected from randomly selected Odontoterme transvaalensis termite mounds, along a dambo transect from the four dambo catena positions namely; margins, midslope; lower slope and the bottom (Figure 2). The number of replicates varied with catena position as there was the mound density varied with catena position. The numbers of replicates were $6,14,4$ and 4 for margins, midslope; lower slope and the bottom respecttively. The coordinates of the sampled termite mounds are shown in Figure 3.

\subsection{Termite Mound Distribution along a Dambo Catena}

An area of 1 hectare $\left(100 \times 100 \mathrm{~m}^{2}\right)$ was randomly selected from the margins, mid-slope; lower slope and bottom catena positions at the study site. The total number of termite mounds in a hectare was recorded. The number of mounds in each catena position were then divided into active and non-active termite mounds. Active mounds were the ones where there were termites in the ventilation pipes, and recent termite mound building activity was clear, while none active mounds were abandoned mounds with no visible sign of termite activity. The height and diameter of the mounds, the coordinates and soil temperature were recorded.

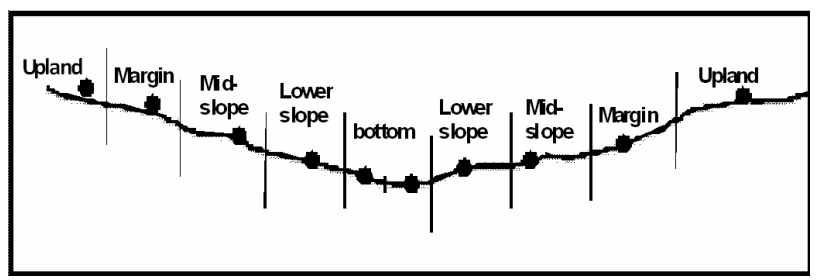

Figure 2. Schematic dambos cross section showing the different catena positions along a dambo transect.

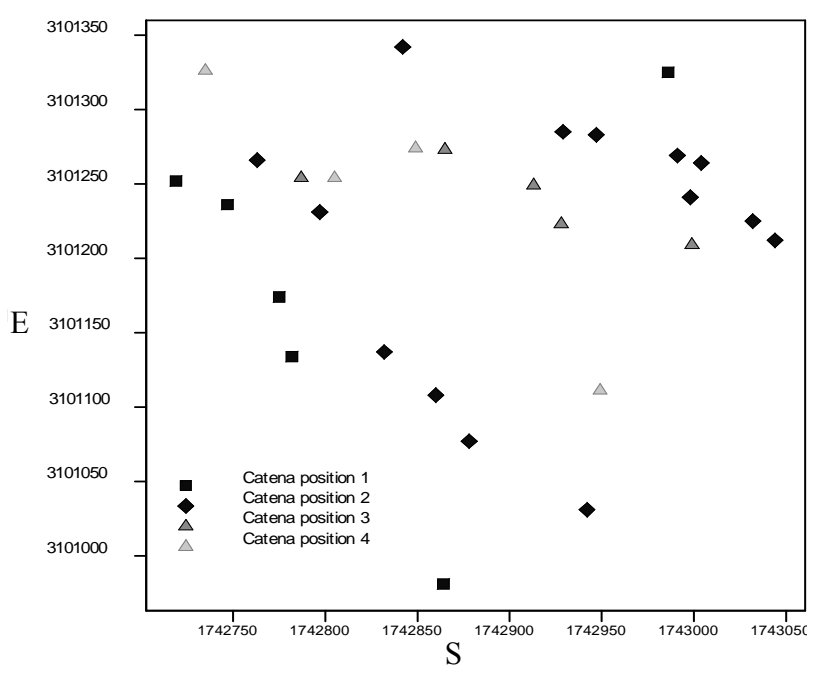

Figure 3. A scatter map showing coordinates (E=Easting's and S=Southing's) in degrees and distribution of sampled termite mounds across the dambo.

\subsection{Measurements of GHG Emissions From Termite Mounds}

To quantify GHG emissions from termite mounds, air samples were collected from the termite mounds using static chambers [25] with a volume of $0.08 \mathrm{~m}^{3}$ which were placed at the top of the termite mound and driven into the soil for about $0.1 \mathrm{~m}$. The chambers were placed on the central ventilation pipe. All the vents on the side walls of the mound were closed and only the central vent at the top was left open. Greenhouse gas samples were collected through the air tight septum at the top of the chamber. Samples were collected at time 0, 30 and 60 minute intervals. Gas samples were collected from 30 termite mounds within 12 hours during the first week of May 2011 to reduce temporal variations (Figure 3). Samples were collected using $20 \mathrm{~cm}^{3}$ syringes before samples were injected into evacuated Labco glass vials. After collecting gases, a few termites were collected from each mound and sent to the laboratory for species identification. The sampling period coincided with the end of the rain season and the beginning of the dry season which runs from May to October. During this period no rainfall was received, but some sections of the dambos were still saturated.

\subsection{Data Analyses and Data Processing}

Gas samples were analysed for the three GHGs using a gas chromatography (Shimadzu GC 2014 model) equipped with a flame ionising detector (GC/FID) at Washington State University, USDA Research Laboratory, USA, Methane standards from Matheson Tri-gas, USA. Samples were shipped to the USA by courier soon after sampling for analysis. The shipment process was assumed to result in negligible changes in the concentration of GHGs of the samples, as standards that were shipped to and from the USA in earlier study remained unchanged [30]. Fluxes for $\mathrm{CH}_{4}, \mathrm{CO}_{2}$ and $\mathrm{N}_{2} \mathrm{O}$ were calculated as described by Khalil and Rasmussen [31] as shown in Equation (1).

$$
F=\gamma\left[\frac{M}{N_{O}} \rho \frac{V}{A}\right] \frac{\mathrm{d} C}{\mathrm{~d} t}
$$

where $\mathrm{F}=$ is the measured fluxes, $\mathrm{C}$ is the measured concentration in the chamber and $\mathrm{dC} / \mathrm{dt}$ is the rate of accumulation in ppbv/min. A is the area from which GHGs were emitted into the chamber $\left(\mathrm{m}^{2}\right)$, V is the volume of the chamber $\left(\mathrm{m}^{3}\right), \mathrm{N}_{0}$ is Avogadros number $(6.02 \times$ $\left.10^{23}\right), \rho$ is the density of air molecule $\left(\mathrm{g} \cdot \mathrm{m}^{-3}\right), \gamma$ is a unit conversion factor equal to $6.0 \times 10^{-5} \mathrm{mg} \cdot \mathrm{min}^{-1} \cdot \mathrm{g} \cdot \mathrm{hr}^{-1}$. $\mathrm{ppbv}^{-1}$, and $\mathrm{M}$ is the molecular weight of the gas.

Data was validated by considering the linearity of the accumulation of the GHGs at times 0, 30 and 60 minutes. 
At times the $r^{2}$ values were $>0.99$, however all the $r^{2}$ values that were $\geq 0.80$ of the flux were accepted. All data was then analyzed for variance (ANOVA) using Genstat Statistical package [32]. Significant differences were separated using least significant differences (LSD). Variability of the data was also analyzed using classical statistical methods and mean, median, skewness, minimum, and maximum values were obtained using the data analysis tool pack of Microsoft Office Excel 2003.

\section{Results}

\subsection{Distribution of Termites Mounds in Dambos}

Termite mound density varied with catena position of the dambo. Termite mound density was highest in the margin and mid slope when compared to the lower slope and the bottom positions. The mound density decreased down the dambo catena. The average termite mound density was $17,18,14$ and 8 mounds $\mathrm{ha}^{-1}$ for the margin, mid-slope, lower slope and bottom catena position respectively (Table 1). However, the density of termite mounds in the lower slope was not significantly different from the margin and mid-slope. On average $61 \%$ of termite mounds per hectare were active, while $39 \%$ were not active. The average termite mound height was $1.2 \mathrm{~m}$, while the average diameter was $3.4 \mathrm{~m}$. However, the margin had mounds with the largest diameter and height (Table 1).

\subsection{Nitrous Oxide, $\mathrm{CH}_{4}$ and $\mathrm{CO}_{2}$ Emission from Termite Mounds}

The average $\mathrm{N}_{2} \mathrm{O}$ emissions from dambo termites were $88 \mu \mathrm{g} \mathrm{N}_{2} \mathrm{O}-\mathrm{N} \mathrm{m}^{-2} \mathrm{hr}^{-1}$. The $\mathrm{N}_{2} \mathrm{O}$ fluxes were not significantly different $(\mathrm{p}>0.05)$ among the different catena positions. Nitrous oxide fluxes were 50,100, 115 and 74 $\mu \mathrm{g} \cdot \mathrm{m}^{-2} \cdot \mathrm{hr}^{-1}$ for the margins, mid-slope, lower slope and bottom catena positions, respectively (Table 2).

The average $\mathrm{CH}_{4}$ emissions from termite mounds were $0.78 \mathrm{mg} \cdot \mathrm{m}^{-2} \cdot \mathrm{hr}^{-1}$. Fluxes varied significantly down the dambo and were $0.48,0.72,1.35$ and $0.79 \mathrm{mg} \cdot \mathrm{m}^{-2} \cdot \mathrm{hr}^{-1}$ for the margins, mid-slope, lower slope and the bottom catena positions respectively (Table 2). Fluxes were highest in the lower-slope, while they were comparable in the margin, mid-slope and bottom catena positions.

Table 1. A summary of termite mound distribution along the dambo catena.

\begin{tabular}{cccccc}
\hline $\begin{array}{c}\text { Catena } \\
\text { Position }\end{array}$ & Mounds ha $^{-1}$ & Soil pH & $\begin{array}{c}\text { Textural } \\
\text { class }\end{array}$ & $\begin{array}{c}\text { Height } \\
(\mathrm{m})\end{array}$ & $\begin{array}{c}\text { Diameter } \\
(\mathrm{m})\end{array}$ \\
\hline Margin & 17 & 6.6 & Sandy clay & 1.4 & 11.9 \\
Midslope & 18 & 6.5 & Clay & 1.1 & 6.3 \\
Lower slope & 14 & 6.7 & Clay & 1.1 & 4.2 \\
Bottom & 8 & 6.7 & Clay & 1.4 & 4.8 \\
Mean & 14 & 6.6 & & 1.2 & 3.4 \\
\hline
\end{tabular}

Table 2. GHG fluxes from termite mounds along the dambo catena.

\begin{tabular}{ccccc}
\hline $\begin{array}{c}\text { Catena } \\
\text { Position }\end{array}$ & $\begin{array}{c}\text { Mean } \mathrm{N}_{2} \mathrm{O} \\
\text { fluxes } \\
\left(\mu \mathrm{g} \cdot \mathrm{m}^{-2} \cdot \mathrm{h}^{-1}\right)\end{array}$ & $\begin{array}{c}\text { Mean } \mathrm{CH}_{4} \\
\text { fluxes } \\
\left(\mathrm{mg} \cdot \mathrm{m}^{-2} \cdot \mathrm{h}^{-1}\right)\end{array}$ & $\begin{array}{c}\text { Mean } \mathrm{CO}_{2} \\
\text { fluxes } \\
\left(\mathrm{mg} \cdot \mathrm{m}^{-2} \cdot \mathrm{h}^{-1}\right)\end{array}$ & $\mathrm{CH}_{4} / \mathrm{CO}_{2}$ \\
\hline Margin & $50^{\mathrm{a}}$ & $0.48^{\mathrm{a}}$ & $1173.7^{\mathrm{a}}$ & $4.1 \times 10^{-4}$ \\
Midslope & $100^{\mathrm{a}}$ & $0.72^{\mathrm{a}}$ & $1440.7^{\mathrm{a}}$ & $5.0 \times 10^{-4}$ \\
Lower slope & $115^{\mathrm{a}}$ & $1.35^{\mathrm{b}}$ & $1798.7^{\mathrm{b}}$ & $7.5 \times 10^{-4}$ \\
Bottom & $74^{\mathrm{a}}$ & $0.79^{\mathrm{a}}$ & $922.8^{\mathrm{a}}$ & $8.5 \times 10^{-4}$ \\
Lsd & 88 & 0.55 & 712 & \\
\hline
\end{tabular}

Different superscripts in the same column indicate significant difference at $\mathrm{p}$ $<0.05$.

The average dambo termite mound emissions for $\mathrm{CO}_{2}$ were $1361 \mathrm{mg} \cdot \mathrm{m}^{-2} \cdot \mathrm{hr}^{-1}$. The $\mathrm{CO}_{2}$ fluxes were significantly different and were 1173.7, 1440.7, 1798.7 and 922.8 $\mathrm{mg} \cdot \mathrm{m}^{-2} \cdot \mathrm{hr}^{-1}$ for the margins, mid-slope, lower slope and bottom catena positions respectively (Table 2). Fluxes were highest in the lower-slope, while they were comparable in the margin, mid-slope and bottom catena positions.

A correlation test showed that there was no relationship between GHGs fluxes and mound diameter or mound height, and this suggests that GHG fluxes were not dependent on height and size (diameter). The ratio of $\mathrm{CH}_{4}$ to $\mathrm{CO}_{2}$ (Table 2) was relatively constant. The ratio ranged from $4.1 \times 10^{-4}-8.5 \times 10^{-4}$ from the margin to the bottom. Variability in mound density and GHG emissions from termite mounds were also expressed by ranking the coefficient of variation (CV) into different classes, for example; low $(<15 \%)$, moderate $(15 \%-35 \%)$, and high $(>35 \%)$, [33]. The CV was high $(>35 \%)$ for all the GHGs and was $58.1 \%, 67.1 \%$ and $47.5 \%$ for $\mathrm{N}_{2} \mathrm{O}, \mathrm{CH}_{4}$ and $\mathrm{CO}_{2}$ respectively (Table 3). The mean and median values were used as primary estimates of the central tendency, and the standard deviation (SD), CV, skewness, minimum, and maximum values were used as the estimates of variability of GHG emissions from the termite mounds. The standard deviation for the GHGs was large and this resulted in large CVs.

\subsection{Mound Based Upscaling of GHG Emissions}

The $\mathrm{N}_{2} \mathrm{O}, \mathrm{CH}_{4}$ and $\mathrm{CO}_{2}$ emissions were upscaled by multiplying the fluxes by the average number of termite mounds per hectare. The mean emissions from dambo termite mounds were $1.23 \mathrm{mg} \mathrm{N} \mathrm{O}_{2} \mathrm{ha}^{-1} \cdot \mathrm{hr}^{-1}(29.6 \mathrm{mg}$ $\mathrm{N}_{2} \mathrm{O}$ ha $^{-1} \cdot$ day $^{-1}$ ). Using the mean daily emission per hectare, annual $\mathrm{N}_{2} \mathrm{O}$ emissions from clay dambos can be estimated to be $10804 \mathrm{mg}(10.8 \mathrm{~g}) \mathrm{N}_{2} \mathrm{O} \mathrm{ha}{ }^{-1} \cdot \mathrm{yr}^{-1}$.

The estimated annual fluxes of $\mathrm{N}_{2} \mathrm{O}$ from the 128,000 ha which is occupied by clay dambos [14] is $1.4 \times 10^{6} \mathrm{~g}$ $(0.00014 \mathrm{Gg})$. Estimated daily emissions were 262.1 and $4569.6 \mathrm{~g} \cdot \mathrm{ha}^{-1} \cdot$ day $^{-1}$ for $\mathrm{CH}_{4}$ and $\mathrm{CO}_{2}$ respectively, while annual emissions were estimated to be 95.7 and $1.7 \times 10^{6}$ $\mathrm{g} \cdot \mathrm{ha}^{-1}$ for $\mathrm{CH}_{4}$ and $\mathrm{CO}_{2}$ respectively (Table 4). The esti- 
Table 3. Variation in termite mound density and GHG emissions along the dambo catena.

\begin{tabular}{ccccccccc}
\hline & Mean & Median & $\begin{array}{c}\text { Standard } \\
\text { Deviation }\end{array}$ & CV (\%) & Kurtosis & Skewness & Min. & Max. \\
\hline $\mathrm{N}_{2} \mathrm{O}\left(\mu \mathrm{g} \mathrm{m}^{-2} \mathrm{~h}^{-1}\right)$ & 88.2 & 66.8 & 75.1 & 85.1 & 2.6 & 1.6 & 9.4 & 324 \\
$\mathrm{CH}_{4}\left(\mathrm{mg} \mathrm{m}^{-2} \mathrm{~h}^{-1}\right)$ & 0.79 & 0.74 & 0.53 & 67.1 & 3.9 & 1.4 & 0.01 & 2.6 \\
$\mathrm{CO}_{2}\left(\mathrm{mg} \mathrm{m}^{-2} \mathrm{~h}^{-1}\right)$ & 1360 & 1182 & 645.8 & 47.5 & -0.7 & 0.5 & 489.6 & 2817.3 \\
\hline
\end{tabular}

$\mathrm{CV}$ is the coefficient of variation, $\mathrm{CV}=$ standard deviation/mean. Low variation $=(\mathrm{CV}<15 \%)$, moderate $=(\mathrm{CV}=15 \%-35 \%)$, and high $=(\mathrm{CV}>35 \%),(\mathrm{Wild}-$ ing, 1985). Min = minimum, max. = maximum.

Table 4. Estimated fluxes, using the termite mound based upscaling.

\begin{tabular}{ccccc}
\hline & Mean measured fluxes & $\begin{array}{c}\text { Mean daily fluxes } \\
\left(\mathrm{mg} \cdot \mathrm{ha}^{-1} \cdot \mathrm{day}^{-1}\right)\end{array}$ & ${\text { Estimates annual flux } \mathrm{g} \cdot \text { ha }^{-1}}^{\text {Estimated National fluxes }(\mathrm{g})}$ \\
\hline $\mathrm{N}_{2} \mathrm{O}$ & $88 \mathrm{\mu g} \cdot \mathrm{m}^{-2} \cdot \mathrm{h}^{-1}$ & 29.6 & 10.8 & $1.4 \times 10^{6}$ \\
$\mathrm{CH}_{4}$ & $0.78 \mathrm{mg} \cdot \mathrm{m}^{-2} \cdot \mathrm{h}^{-1}$ & 262.1 & 95.7 & $1.2 \times 10^{7}$ \\
$\mathrm{CO}_{2}$ & $13,601 \mathrm{mg} \cdot \mathrm{m}^{-2} \cdot \mathrm{h}^{-1}$ & 4569.6 & $1.7 \times 10^{6}$ & $2.2 \times 10^{11}$ \\
\hline
\end{tabular}

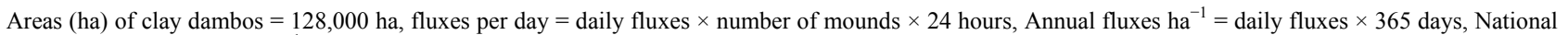
fluxes $(\mathrm{g})=$ annual fluxes $\mathrm{ha}^{-1} \times$ area covered by clay dambos.

mated annual fluxes from clay dambos were $1.2 \times 10^{7}$ $(0.0012 \mathrm{Gg})$ for $\mathrm{CH}_{4}$ and $2.2 \times 10^{11}(220 \mathrm{Gg})$ for $\mathrm{CO}_{2}$ (Table 4).

\section{Discussions}

Greenhouse gas emissions from tropical dambo ecosystems have largely not been investigated. To the best of our knowledge this paper reports the first GHG emissions from dambo located Odontoterme transvaalensis termite mounds from Zimbabwe. Other studies from the tropics that have reported GHG fluxes from termite mounds have reported fluxes from other savanna ecosystems e.g. uplands and grasslands $[21,25]$.

The density of termite mounds was highest in the margin position where the soils are much drier and in the mid-slope, where there is plenty of vegetation growth and soil organic matter which provided feed for termites. The termite mound density decreased down the catena, and was lowest in the drier bottom [34], which also had lower vegetation cover and soil organic matter. The mound density was comparable to other studies $[27,18]$. The bottom catena had a lower number of replicates because they had a lower mound density (Table 1). The mound diameter also decreased from the margin to the bottom (Table 1).

Measurements that were carried out in dambo located termite mounds showed that dambo located O.transvaalensis termite mounds are sources of GHGs which are emitted into the atmosphere, thus they contribute to atmospheric GHGs. In the nitrogen depleted soils of the tropics, microbiological processes in soils are the major source of atmospheric $\mathrm{N}_{2} \mathrm{O}$.

In the tropics the limiting factor to $\mathrm{N}_{2} \mathrm{O}$ production is mainly the low levels of nitrogen in the soils. The large mineralization fluxes indicate that turnover of organic matter by soil-feeding termites represents a significant input of inorganic nitrogen in tropical soils [35]. Nitrous oxide is a by-product of nitrification and an intermediate product of denitrification. Biological $\mathrm{N}_{2} \mathrm{O}$ can be produced from nitrification under aerobic conditions (Equation (1)).

$$
\mathrm{NH}_{4}^{+} \rightarrow \mathrm{N}_{2} \mathrm{O} \rightarrow \mathrm{NO}_{2^{-}} \rightarrow \mathrm{NO}_{3^{-}}
$$

Denitrification is generally believed to be the major source of soil $\mathrm{N}_{2} \mathrm{O}$ and occurs under moderately reducing conditions (Equation (2)). This process may explain $\mathrm{N}_{2} \mathrm{O}$ emissions in dambos which are seasonally saturated.

$$
\mathrm{NO}_{3} \rightarrow \mathrm{N}_{2} \mathrm{O} \rightarrow \mathrm{NO} \rightarrow \mathrm{N}_{2}
$$

The $\mathrm{N}_{2} \mathrm{O}$ emissions were highest in the saturated midslope and lower slope catena positions, and this may suggest that denitrification was faster than nitrification which took place in the less saturated margin and the bottom catena position. The $\mathrm{N}_{2} \mathrm{O}$ fluxes were lower at the dambo bottom catena position. In most of Zimbabwe's dambos, conditions become drier towards the centre [36], and in some dambos the lowest part of the dambo may be dry throughout the year, except immediately after the rains and it supports less vegetation of a similar density to that in the margins, thus less biomass was available for termite consumption [34]. The $\mathrm{N}_{2} \mathrm{O}$ fluxes from the margin and the bottom were indeed comparable and were 50 and $74 \mu \mathrm{g} \mathrm{N}_{2} \mathrm{O} \mathrm{m}^{-2} \cdot \mathrm{hr}^{-1}$ (Table 2).

The average $\mathrm{CH}_{4}$ and $\mathrm{CO}_{2}$ emissions were higher in the mid-slope and lower slope (Table 2), and this can also be attributed to the availability of plenty of forage/ food that was used for respiration by termites. From studies carried out in tropical savannas of Australia, sub- 
terranean termites graze about $100 \mathrm{~kg} \cdot \mathrm{ha}^{-1}$ [37] and [22] estimated emissions of $\mathrm{N}_{2} \mathrm{O}$ from termites to be $0.0125 \%$ of the weight of the carbon consumed assuming a fixed $\mathrm{C}: \mathrm{N}$ ratio, and of the carbon consumed by termites, $1.23 \%$ (average of measured emissions) is emitted in the form of methane while the remainder is emitted as $\mathrm{CO}_{2}$.

The mid-slope and lower slope catena positions also had suitable anaerobic conditions that ensured $\mathrm{CH}_{4}$ formation as they were saturated for long periods when compared to other catena positions [34,38]. The mid-slope and lower slope catena positions also showed decreasing soil particle size $(9,13]$ and increasing proportion of active clays relative to kaolinite [16]. The nature of the clay affects $\mathrm{CH}_{4}$ emission because some clay types protect organic matter from mineralisation which delays methanogenesis, while soils rich in swelling clays (active) are usually more favourable to methanogenesis than sandy soils or soils rich in kaolinite [5].

The mean $\mathrm{N}_{2} \mathrm{O}$ fluxes from dambo termite mounds reported in this paper are higher than the end of rain season means reported for other termite mounds from Africa. [28] reported dry period fluxes of $6-36 \mu \mathrm{g} \mathrm{N}_{2} \mathrm{O} \mathrm{m}^{-2} \cdot \mathrm{hr}^{-1}$, with mean fluxes of $20 \mu \mathrm{g} \mathrm{N} \mathrm{O} \mathrm{m}^{-2} \cdot \mathrm{hr}^{-1}$ at the end of the rainy season from upland termite mounds from tropical savannas of Burkina Faso. Higher fluxes $\left(88 \mu \mathrm{g} \mathrm{N} \mathrm{N}_{2} \mathrm{O}\right.$ $\mathrm{m}^{-2} \cdot \mathrm{hr}^{-1}$ ) from the dambo termite mounds at the end of the rainy season can be a result of plenty of vegetation and soil organic matter which is consumed by the termites in these organic matter rich dambos. However, the $\mathrm{N}_{2} \mathrm{O}$ emissions from termite mounds reported in this study were comparable to re-calculated fluxes from temperate forest soils of $10-17 \mathrm{~g} \mathrm{~N}_{2} \mathrm{O} \mathrm{ha}^{-1} \cdot \mathrm{yr}^{-1}$ [39].

The mean $\mathrm{N}_{2} \mathrm{O}$ fluxes reported in this study are higher and more than double the fluxes reported from other ecosystems of the savannas in Zimbabwe and the region, showing that termite mounds are a hotspot for $\mathrm{N}_{2} \mathrm{O}$. [40] reported $\mathrm{N}_{2} \mathrm{O}$ fluxes ranging from 0.5 to $35.7 \mu \mathrm{g} \mathrm{N}_{2} \mathrm{O}$ $\mathrm{m}^{-2} \cdot \mathrm{hr}^{-1}$ in upland soils at the same study site from the dry to the rain season. [41] reported highest $\mathrm{N}_{2} \mathrm{O}$ fluxes of $42 \mu \mathrm{g} \mathrm{N}_{2} \mathrm{O} \mathrm{m}{ }^{-2} \cdot \mathrm{hr}^{-1}$ from miombo woodlands, while Werner et al. (2007) reported mean $\mathrm{N}_{2} \mathrm{O}$ emissions of $42.9 \pm 0.7 \mu \mathrm{g} \mathrm{N} \mathrm{m}^{-2} \cdot \mathrm{hr}^{-1}$ from tropical rain forest in Kenya.

Methane fluxes from $O$. transvaalensis termite mounds which ranged from $480-1350 \mu \mathrm{g} \cdot \mathrm{m}^{-2} \cdot \mathrm{hr}^{-1}$ were higher than fluxes reported from other tropical ecosystems in Zimbabwe. [40] reported $\mathrm{CH}_{4}$ emissions ranging from $1.9-102 \mu \mathrm{g} \cdot \mathrm{m}^{-2} \cdot \mathrm{hr}^{-1}$ under different landuse systems in Zimbabwe. However, $\mathrm{CH}_{4}$ emissions from dambo termites mounds (mean $=0.78$ and range $0.48-1.35 \mathrm{mg}$. $\mathrm{m}^{-2} \cdot \mathrm{hr}^{-1}$ ) were $12-13.5$ times higher than the emissions from Odontotermes from South Africa which were located in savannas with dense grass cover and some underbrush and had a range of $0.04-0.1 \mathrm{mg} / \mathrm{nest} / \mathrm{hour}$ [25]. The higher fluxes in dambo termite mounds from this study could be attributed to huge amounts of vegetation and soil organic carbon additions in dambos when compared to other savannas that were used in the study by [25]. However, fluxes from termite mounds were lower than emissions reported $9 \mathrm{mg} \mathrm{CH}_{4} \mathrm{~m}^{-2} \mathrm{hr}^{-1}$ or $216 \mathrm{mg}$ $\mathrm{CH}_{4} \mathrm{~m}^{-2}$ day $^{-1}$, by $[42,43]$ from seasonally saturated dambos.

Mapanda et al. (2010) also reported much lower emissions for $\mathrm{CO}_{2}$ for other non-dambo tropical ecosystems (8.4-190.4 $\mathrm{mg} \mathrm{m}^{-2} \mathrm{hr}^{-1}$ ) when compared to a range from 922.9-1798.7 $\mathrm{mg} \mathrm{m}^{-2} \mathrm{hr}^{-1}$ from dambo based O. transvaalensis termite mounds. The measured $\mathrm{CO}_{2}$ emissions were also lower than the reported values by [25], however the $\mathrm{CH}_{4} / \mathrm{CO}_{2}$ ratios were comparable. The higher $\mathrm{N}_{2} \mathrm{O}$ and $\mathrm{CO}_{2}$ emissions from dambo located termite mounds could be attributed to the presence of abundant plant material, organic matter, higher termite populations and residual soil moisture in dambos such that dambo termites would have abundant plant materials to feed on. The GHG fluxes from dambo termite mounds were independent of mound diameter or mound height and soil temperature. The ratio of $\mathrm{CH}_{4}$ to $\mathrm{CO}_{2}$ were also independent of catena position, mound diameter or mound height, soil temperature and a similar observation was made by [25].

Greenhouse gas emissions from termite mounds showed higher standard deviation and a corresponding higher CV (Table 3). The high CV for GHGs may be due to intrinsic (natural variations) or extrinsic (imposed) sources of variability such as management. Intrinsic variability is natural variation in soils [44] and extrinsic variability is caused by factors imposed on a site [45]. Intrinsic factors such as variations in degree of saturation, type of vegetation, clay content and clay mineralogy could also have contributed to the variations in GHG emissions across the dambos.

With an estimated emission of 10.8, 95.6 and $1.7 \times 10^{6}$ $\mathrm{g} \cdot \mathrm{ha}^{-1}$ annually for $\mathrm{N}_{2} \mathrm{O}, \mathrm{CH}_{4}$ and $\mathrm{CO}_{2}$ respectively (Table 4), it is apparent that dambo $O$. transvaalensis termite mounds are an important source of GHGs. Greenhouse gas emissions from dambo termite mounds reported in this study were comparable to other ecosystem e.g. temperate $\mathrm{N}_{2} \mathrm{O}$ emissions [39] and higher than $\mathrm{CH}_{4}$ emissions from $O$. transvaalensis termite mounds from dry tropical soils [25]. Although some studies have argued that the actual termite contribution to gas fluxes remained small in the global context [46,47], the contributions of dambo located $O$. transvaalensis termites to wards total $\mathrm{N}_{2} \mathrm{O}, \mathrm{CO}_{2}$ and $\mathrm{CH}_{4}$ emissions from dambos and from the seasonally dry ecosystems of Africa cannot be ignored. Thus, GHG emissions from dambo located termite mounds should be accounted for when making estimates of $\mathrm{N}_{2} \mathrm{O}$ emissions from the tropics. 


\section{Conclusion}

It was concluded that dambo located $O$. transvaalensis termite mounds are sources of GHGs. The emission of $\mathrm{CH}_{4}$ and $\mathrm{CO}_{2}$ from dambo located termite mounds varied with catena position. Emissions were highest in the lower slope and the mid-slope catena positions which are the wettest sections of the dambo catena. Dambo located termite mounds are highly fertile, have high amounts of soil organic carbon and are an important hotspot of GHGs which should be accounted for when making estimates of GHG emissions from the tropical regions.

\section{Acknowledgements}

We are grateful for funding given to the Department of Soil Science and Agricultural Engineering, University of Zimbabwe by IFS. We would like to thank the staff at the USDA-Agricultural Research Service Laboratory, at Washington State University for gas sample analysis.

\section{REFERENCES}

[1] IPCC, Changes in Atmosphere Constituents and Radiative Forcing. In: S. Solomon, D. Qin, M. Manning, M. Marquis, K. Avery, H. L. Miller and Z. Chen, Eds., Climate Change 2007. The Physical Science Basis: Contribution of Working Group I to the Fourth Assessment Report of the Intergovernmental Panel on Climate Change, Cambridge University Press, New York, 2007, pp. 212213.

[2] IPCC, "The Science of Climate Change," In: J. T. Houghton, L. G. M. Filho, B. A. Callander, N. Harris, A. Kattenberg and K. Maskell, Eds., Intergovernmental Panel on Climate Change, Cambridge University Press. Cambridge, 1995.

[3] L. Marani and P. C. Alvaláa, "Methane Emissions from Lakes and Floodplains in Pantanal, Brazil," Atmospheric Environment, Vol. 41, No. 8, 2006, pp. 1627-1633. doi:10.1016/j.atmosenv.2006.10.046

[4] Environment About, "Residence Times and Global Warming Potential of Greenhouse Gases," 2011. http://www.environmentabout.com/977/.

[5] J. Le Mer and P. Roger, "Production, Oxidation, Emission and Consumption of Methane by Soils: A Review," European Journal of Soil Biology, Vol. 37, No. 1, 2001, pp. 25-50. doi:10.1016/S1164-5563(01)01067-6

[6] E. Matthews, "Wetlands," In: M. A. K. Khalil, Ed., Atmospheric Methane, Its Role in the Global Environment, Spinger-Verlag, Berlin, 2000, pp. 202-233.

[7] B. D. Acres, A. B. Rains, R. B. King, R. M. Lawton and A. J. B. Mitchell, "African Dambos: Their Distribution, Characteristics and Use," In: M. F. Thomas and A. S. Goudie, Eds., Dambos: Small Channelless Valleys in the Tropics, Zeitschrift für Geomorphologie 52, Borntraeger, 1985, pp. 63-86.

[8] A. Bullock, "Dambo Hydrology in Southern AfricaReview and Reassessment," Journal of Hydrology, Vol.
134, No. 1-4, 1992, pp. 373-396. doi:10.1016/0022-1694(92)90043-U

[9] R. Boast, "Dambos-A Review," Progress in Physical Geography, Vol. 14, No. 2, 1990, pp. 153-177. doi: $10.1177 / 030913339001400201$

[10] J. R. E. Hindson, "Protection of Dambos by Means of Contour Seepage Furrows," Ministry of Agriculture, Ndola, 1962.

[11] M. Bell and N. Roberts, "The Political Ecology of Dambo Soil and Water Resources in Zimbabwe," Transactions of the Institute of British Geographers, Vol. 16, No. 3, 1991, pp. 301-318. doi:10.2307/622950

[12] P. M. Grant, "Fertility of Dambo Soils and The Related Response of Dambo Soils to Fertilisers and Manure," In: R. Owen, K. Verbeek, J. Jackson and T. Steenhuls, Eds., Dambo Farming in Zimbabwe, University of Zimbabwe Publications, Harare, 1995, pp. 117-126.

[13] R. Mäckel, "Dambos and Related Landforms in Africa: An Example for the Ecological Approach to Tropical Geomorphology," In: M. F. Thomas and A. S. Goudie, Eds., Dambos: Small Channelless Valleys in the Tropics, Zeitschrift für Geomorphologie 52, Borntraeger, 1985, pp. $1-23$.

[14] J. R. Whitlow, "Dambos in Zimbabwe: A Review," In: M. F. Thomas and A. S. Goudie, Eds., Dambos: Small Channelless Valleys in the Tropics, Zeitschrift für Geomorphologie 52, Borntraeger, 1985, pp. 115-146.

[15] B. L. Mitchell, "Report on A Survey of Termites of Zimbabwe. Occasional papers, National Museum," Rhodesia, Bulletin, Natural Sciences, Vol. 6, No. 5, 1980, pp. 187 323.

[16] R. Mäckel, "Dambos: A Study in Morphodynamic Activity on the Plateau Regions of Zambia," Catena, Vol. 1, 1974, pp. 327-365. doi:10.1016/S0341-8162(73)80018-9

[17] J. M. Dangerfield, T. S. McCarthy and W. N. Ellery, "The Mound Building Termite Macrotermes Michaelseni as an Ecosystem Engineer," Journal of Tropical Ecology, Vol. 14, No. 4, 1998, pp. 507-520. doi: $10.1017 / \mathrm{S} 0266467498000364$

[18] G. Soropa, "Effcets of Termite Mounds on the Distribution of Total Micronutrients (Fe, $\mathrm{Mn}, \mathrm{Zn}$ and $\mathrm{Cu}$ ) Putting Emphasis on the Termite Mounds Occurance and Distribution along a Catena," B.Sc. Dissertation, University of Zimbabwe, Harare, 2004.

[19] W. A. Sands, "Termite Distribution in Man-Modified Habitats in West Africa, With Special Reference to Species Segregation in The Genus Trinervitermes (Isoptera, Termitidae, Nasutitermitinae)," Journal of Animal Ecol$o g y$, Vol. 34, No. 3, 1965, pp. 557-571. doi:10.2307/2449

[20] G. Velu, K. Ramasamy, K. Kumar, N. Sivaramaiah and V. R. M. Ramanjaneya, "Green House Gas Emissions from Termite Ecosystem (A Review)," African Journal of Environmental Science and Technology, Vol. 5, No. 2, 2011, pp. 56-64.

[21] C. Brümmer, H. Papen, R. Wassmann and N. Brüggemann, "Fluxes of $\mathrm{CH}_{4}$ and $\mathrm{CO}_{2}$ From Soil and Termite Mounds in South Sudanian Savanna of Burkina Faso (West Africa)," Global Biogeochemical Cycles, Vol. 23, 
No. GB1001, 2009, 13 pp. doi:10.1029/2008GB003237

[22] M. A. K. Khalil, R. A. Rasmussen, J. R. J. French and J. A. Holt, "Influence of Termites on Atmospheric Trace Gases $\mathrm{CH}_{4}, \mathrm{CO}_{2}, \mathrm{CH}_{3} \mathrm{Cl}, \mathrm{N}_{2} \mathrm{O}, \mathrm{CO}, \mathrm{H}_{2}$ and Light Hydrocarbon," Journal of Geophysical Research, Vol. 95, No. D4, 1990, pp. 3619-3634. doi:10.1029/JD095iD04p03619

[23] S. Konaté, X. Le Roux, B. Verdier and M. Lepage, "Effect of Underground Fungus-Growing Termites on Carbon Dioxide Emission at the Point and Landscape-Scales in an African Savanna," Functional Ecology, Vol. 17, No. 3, 2003, pp. 305-314. doi:10.1046/j.1365-2435.2003.00727.x

[24] S. C. Taylor, P. R. Zimmerman, C. Cumberbatch, J. P. Greenberg, C. Westberg and J. P. E. Darlington, "Measurements and Interpretation of $\delta^{13} \mathrm{C}$ of Methane from Termites, Rice Paddies and Wetlands from Kenya," Global Biogeochemical Cycles, Vol. 2, No. 4, 1988, pp. 341-355. doi:10.1029/GB002i004p00341

[25] W. Seiler, R. Conrad and D. Scharffe, "Field Studies of Methane Emission from Termite Nests into the Atmosphere and Measurement of Methane Uptake by Tropical Soils," Journal of Atmospheric Chemistry, Vol. 1, No. 2, 1984, pp. 171-186. doi:10.1007/BF00053839

[26] P. R. Zimmerman, J. P. Greenberg, S. O. Wandiga and P. J. Crutzen, "Termite, a Potentially Large Source of Atmospheric Methane," Science, Vol. 218, No. 4572, 1982, pp. 563-565. doi:10.1126/science.218.4572.563

[27] G. Schuurman and J. M. Dangerfield, "Dispersion and Abundance of Macrotermes Michaelseni Colonies: A Limited Role for Intraspecific Competition," Journal of Tropical Ecology, Vol. 13, No. 1, 1997, pp. 39-49. doi:10.1017/S0266467400010233

[28] C. Brümmer, H. Papen, R. Wassmann and N. Brüggemann, "Termite Mounds as Hot Spots of Nitrous Oxide Emissions in South-Sudanian Savanna of Burkina Faso (West Africa)," Geophysical Research Letters, Vol. 36, No. 9, 2009, pp. 15-18. doi:10.1029/2009GL037351

[29] V. Vincent and R. G. Thomas, "An Agro-Ecological Survey of Southern Rhodesia: Part I Agro-Ecological Survey. Salisbury," Government Printers, Rhodesia, 1961.

[30] D. J. Brown, G. Nyamadzawo and P. E. Denison, "Spatially Distributed Methane Flux Measurements for a Tropical Dambo Wetland Landscape in Uganda," American Geophysical Union, California, 2008. http://adsabs.harvard.edu/abs/2008AGUFM.B33B0414B.

[31] M. A. K. Khalil and R. A. Rasmussen, "Flux Measurements and Sampling Strategies: Applications to Methane Emissions from Rice Fields," Journal of Geophysical Research, Vol. 103, No. D19, 1998, pp. 25211-25218.

[32] GENSTAT, "GENSTAT Statistical Package," 8th Edition, VSN International, Hertfordshire, 2003.

[33] L. P. Wilding, "Spatial Variability: Its Documentation, Accommodation, and Implication to Soil Surveys," In: D. R. Nielsen and J. Bouman, Eds., Soil Spatial Variability, Wageningen, The Netherlands, 1985, pp. 166-194.

[34] C. J. von der Heyden, "The Hydrology and Hydrogeology of Dambos: A Review," Progress in Physical Geography, Vol. 28, No. 4, 2004, pp. 544-564.

\section{doi:10.1191/0309133304pp424oa}

[35] D. K. Ngugi, R. Ji and A. Brune, "Nitrogen Mineralization, Denitrification, and Nitrate Ammonification by SoilFeeding Termites: A 15N-based Approach," Biogeochemistry, Vol. 103, No. 1-3, 2011, pp. 355-369. doi:10.1007/s10533-010-9478-6

[36] J. M. Rattray, R. M. M. Cormack and R. R. Staples, "The Vlei Areas of Southern Rhodesia and Their Uses," Rhodesian Agricultural Journal, Vol. 50, No. 6, 1953, pp. 465-483.

[37] J. J. Mott, J. Williams, M. H. Andrew and A. N. Gillison, Australian Savanna Ecosystems. In: J. C. Tothill and J. J. Mott, Eds., Ecology and Management of the World's Savannas, Australian Academy of Sciences, Canberra, 1985, pp. 56-82.

[38] M. Bell, R. Faulkner, P. Hotchkiss, R. Lambert, N. Roberts and A. Windram, "The Use of Dambos in Rural Development with Reference to Zimbabwe," ODA Project, London, 1987.

[39] R. D. Bowden, P. A. Stuedler, J. M. Mellillo and J. D. Abber, "Annual Nitrous Oxide Fluxes from Temperate Forest Soils in the North Easstern United States," Journal of Geophysical Research, Vol. 95, No. D9, 1990, pp. 13997-14005. doi:10.1029/JD095iD09p13997

[40] F. Mapanda, J. Mupini, M. Wuta, J. Nyamangara and R. M. Rees, "A Cross-Ecosystem Assessment of the Effects of Land Cover and Land Use on Soil Emission of Selected Greenhouse Gases and Related Soil Properties in Zimbabwe," European Journal of Soil Science, Vol. 61, No. 5, 2010, pp. 721-733. doi:10.1111/j.1365-2389.2010.01266.x

[41] R. M. Rees, M. Wuta, P. A. Furley and C. S. Li, "Nitrous Oxide Fluxes from Savanna (Miombo) Woodlands in Zimbabwe," Journal of Biogeography, Vol. 33, No. 3, 2006, pp. 424-437. doi:10.1111/j.1365-2699.2005.01423.x

[42] M. Scholes and M. O. Andreae, "Biogenic and Pyrogenic Emissions from Africa and Their Impact on the Global Atmosphere," AMBIO, Vol. 29, No. 1, 2000, pp. 23-29.

[43] B. B. Otter and M. C. Scholes, "Methane sources and Sinks in Periodically Flooded South African Savanna," Global Biogeochemical Cycles, Vol. 14, No. 1, 2000, pp. 97-111. doi:10.1029/1999GB900068

[44] C. A. Cambardella, T. B. Moorman, J. M. Novak, T. B. Parkin, D. L. Karlen, R. F. Turco and A. E. Konopka, "Field Scale Variability of Soil Properties in Central Iowa soils," Soil Science Society of America Journal, Vol. 58, No. 5, 1994, pp. 1501-1511.

doi:10.2136/sssaj1994.03615995005800050033x

[45] P. S. C. Rao and R. J. Wagenet, "Spatial Variability of Pesticides in Field Soils: Methods for Data Analysis and Consequences," Weed Science, Vol. 33, No. 5, 1985, pp. 18-24.

[46] P. Eggleton, R. Homathevi, D. T. Jones, D. Mac, J. Fonald, D. Jeeva, D. E. Bignell and M. Maryati, "Termite Assemblages, Forest Disturbance and Greenhouse Gas Fluxes in Sabah, East Malysia," Philosophical Transactions of the Royal Society, Series B, Vol. 354, No. 1391, 1999, pp. 1791-1802. doi:10.1098/rstb.1999.0521 
[47] A. Sugimoto, D. E. Bignell and J. A. MacDonald, "Global Impact of Termites on the Carbon Cycle and Atmospheric Trace Gases," In: T. Abe, D. E. Bignell and M. Higashi, Eds.,
Termites: Evolution, Sociality, Symbiosis, Ecology, Kluwer Academic Publishers, Dordrecht, 2000, pp. 409-435. 